\title{
Spectrophotometric Determination of Carbofuran with Diazotized Benzidine in Environmental Water Samples
}

\author{
Saadiyah A. Dhahir \\ Noor J. Mohammed \\ Shetha F. Narren \\ Department of chemistry, College of science for women, University of Baghdad \\ E-mail:sadiataher@yahoo.com.
}

Received 25/5/2015

Accepted 10/ 6/2015

(c) (1) $9 \Theta$

This work is licensed under a Creative Commons Attribution-NonCommercialNoDerivatives 4.0 International Licens

\begin{abstract}
:
A simple, rapid, accurate and sensitive spectrophotometric method has been developed for the determing carbamate pesticides in both pure and water samples. The method is appropriate for the determination of carbofuran in the presence of other ingredients that are usually available in dosage forms. The effect of organic solvents on the spectrophotometric properties of the azo dye and the structure of the resulting product have also been worked out and it is found to be 1:1 benzidine :carbofuran. The method can be successfully applied to determination of carbofuran in water samples. The method is based on diazotization of Benzidine (4, 4- diamino biphenyl) with sodium nitrite and hydrochloric acid followed by coupling with carbofuran in alkaline medium to form a yellow colored azo dye having the absorption maximum at $429 \mathrm{~nm}$ against reagent blank solution. Beer's law is obeyed in the concentration range of $(0-14) \mu \mathrm{g}$ of $10 \mathrm{~mL}$ carbofuran. Molar absorptivity of $1 \times 10^{4} \mathrm{~L}_{\mathrm{mol}}{ }^{-1} . \mathrm{cm}^{-1}$ which depend on the concentration level of carbofuran.
\end{abstract}

Key words: Carbofuran, Benizidine, Determination, Azo Dye, Spectrophotometery

\section{Introduction:}

Carbofuran (2, 3-dihydro-2, 2-dimethyl7 - benzofuranol N-methy carbamate) is one of the carbamate pesticides, a large family of pesticides derived from carbamic acid [1] is shown in Figure

(1) The toxicity of pesticides and their degradation products are making these chemical substances a potential hazard by contaminating our environment [2-3] Due to a highly toxicity of carbofuran , it is essential to develope accurate and reliable methods of monitoring their levels for safety purposes. Earlier techniques used for carbofuran assassment were including [4-5] Gas Chromatography(GC) [6-7] ,GLC [8-9]
.High Performance Liquid Chromatography (HPLC) [10], and spectrophotometric techniques [11]. Some of these reported methods need costly instruments, laborious procedure and less sensitive these facts have promoted the authors to develop sensitive and cost effective method. The proposed method is based on the coupling of hydrolyzed carbofuran with diazotized benzidine in alkaline medium which gives a yellow product having the absorption as medium at $429 \mathrm{~nm}$. 


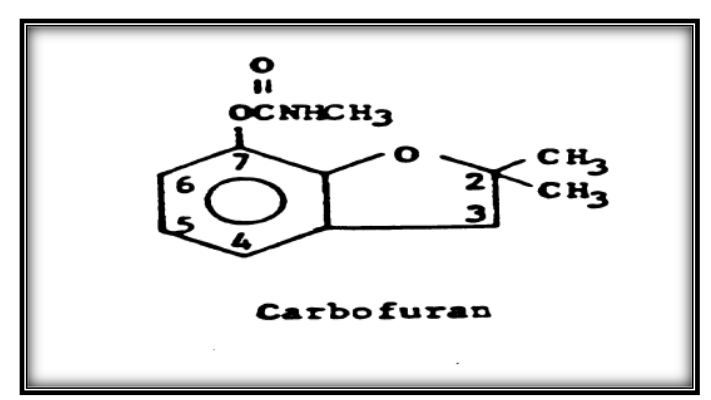

Fig. (1) The Structure of Carbofuran [12]

\section{Materials and Methods: Apparatus}

UV-Visible recording spectrophotometer Shimadzu Model 160A (Japan) with a response time of $0.1 \mathrm{~s}$, is used for spectrophotomatric determination A quartz cell of $5 \mathrm{~mL}$ internal volume and $1 \mathrm{~cm}$ path length is used for absorbance measurements .

Hotplate Stirrer (Hotplate stirrer Model L-81 Labincobv).

Electric Balance ( Sartorius, 4digitals, made in Germany ).

Oven (Memmert, maximum temperature 250,made in western Germany).

\section{Chemicals and Reagent}

A Standard Carbofuran (99\% purity) is purchased from USA (Accustandard) and Carbofuran-3-hydroxy $\quad(98.8 \%$ purity) is purchased from SigmaAldrich.

All other chemicals used in the study are of analytical reagent (AR) grade.

Preparation of Standard Solutions:

All glassware used are supplied and cleaned with distilled water and dried at $50^{\circ} \mathrm{C}$ for $30 \mathrm{~min}$ prior to use. Batch experiments are carried out to ensure the reproducibility of results and the average value. All reagents used are of the highest purity and most solutions are prepared in ultra pure water and Dieonized water.

A standard stock solution of $250 \mathrm{ppm}$ of carbofuran is prepared by dissolving $0.25 \mathrm{~g}$ of the solid carbofuran in $1000 \mathrm{ml}$ of deionized water. A working standard solution of $100 \mathrm{ppm}$ of carbofuran is prepared by diluting the stock one with deionized water.

A standard solution of Benzidine of 100 ppm is daily prepared by dissolving $0.01 \mathrm{~g}$ of the solid product in $5 \mathrm{~mL}$ of ethanol and filled to the mark with deionized water in to $100 \mathrm{~mL}$ volumetric flask.

A standard solution of sodium nitrite $(1 \%)$ is prepared by dissolving $(1,00 \mathrm{~g})$ of the solid product in $100 \mathrm{~mL}$ of deionized water.

A standard solution of sodium carbonate $(1 \mathrm{M})$ is prepared by dissolving $(11.6 \mathrm{~g})$ of the solid product in $100 \mathrm{~mL}$ of deionized water

A standard solution of hydrochloric acid $(1 \mathrm{M})$ is prepared by $10 \mathrm{~mL}$ of stock solution was add to $100 \mathrm{~mL}$ volumetric flask diluted up to the mark by deionized water .

A standard solution of sulphamic acid $(0.1 \%)$ is prepared by $0.1 \mathrm{~mL}$ of stock solution added to $100 \mathrm{~mL}$ volumetric flask diluted to mark with deionized water.

\section{Interference Solutions of $\mathbf{1 0}$ ppm}

These solutions are prepared by dissolving $0.001 \mathrm{~g}$ of each substance in a suitable solvent (water or ethanol) and then completing the volume to $100 \mathrm{~mL}$ with distilled water.

\section{Solutions of Surface Active Substances $(0.1 \%)$}

These solutions are prepared by dissolving $0.1 \mathrm{~g}$ of each substance in distilled water and then completing the volume to $100 \mathrm{~mL}$ with distilled water CTAB (Cetyltrimethyl ammonium bromide) SDS (Sodium dodecyl sulphate)

Triton- $\quad \times 100 \quad$ (Iso-octylphenoxypolyethoxy ethanol)

Tween

20(Polyoxyethylenesorbitanmonolauate) 
General Procedure for Direct Determination of Carbofuran Using Diazotization Coupling Reaction

$0.5 \mathrm{~mL}$ from $100 \mathrm{ppm}$ of Benzidine transferred to $10 \mathrm{~mL}$ volumetric flask then $0.5 \mathrm{~mL}$ of concentrated of $1 \% \mathrm{NaNO}_{2}$ is added Then, $0.5 \mathrm{~mL}$ of $1 \mathrm{M}$ of HCI is added. The mixture is shaken and cooled in ice bath for $5 \mathrm{~min}$ then added The following $0.5 \mathrm{~mL}$ of sulphamic acid ,10ppm of carbofuran, $0.5 \mathrm{~mL}$ of $1 \mathrm{M}$ of $\mathrm{Na}_{2} \mathrm{CO}_{3}$ are added and $0.5 \mathrm{~mL}$ of $0.1 \%$ of Tween 20 is added and the volume was made up to $10 \mathrm{~mL}$ with deionized water. Absorbance measurements are carried out at $429 \mathrm{~nm}$ for the yellow color by using a $1.0 \mathrm{~cm}$ quartz cell against reagent blank which is prepared in the same way but without carbofuran.

\section{Results and Discussion:}

\section{Absorption Spectra}

A yellow -colored oxidizing coupling product with maximum absorption at $429 \mathrm{~nm}$ after studing of the Optimum Reaction Conditions is formed when carbofuran is allowed to react with benzidine in basic medium (sodium carbonate). Figure (2) shows the absorption spectra of yellow product formed so the absorption maximum at $429 \mathrm{~nm}$ is used in all subsequent experiments.

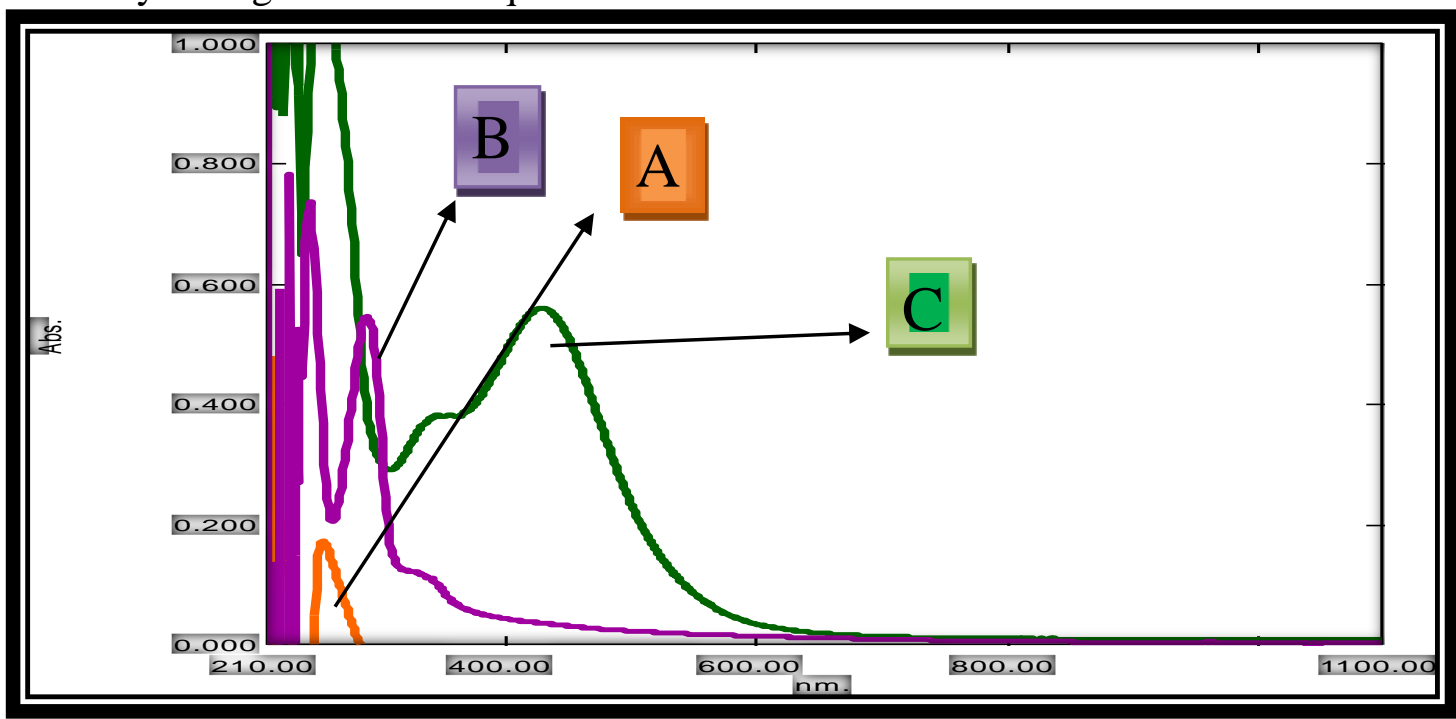

Fig. (2): A. The Absorption Spectrum of the Carbofuran Versus Distilled Water

B. The Absorption Spectrum of the Benzidine Versus Distilled Water

C. The Absorption Spectrum of Carbofuran With reagent Benzidine Versus Blank

\section{Study of the Optimum Reaction Conditions}

The effect of various parameters on the absorption intensity of the aso dye formed is studied and the reaction conditions are optimized. The factor affecting color development, reproducibility, sensitivity and conformity with Beers law is carbofuran with reagent benizdine.
Effect of Type of Acid on Diazotization

In order to select the most suitable acid used in the diazotization of carbofuran, different types of $1 \mathrm{M}$ acids $(\mathrm{HCl}$, $\mathrm{H}_{2} \mathrm{SO}_{4}, \mathrm{HNO}_{3}, \mathrm{H}_{3} \mathrm{PO}_{4}$, and $\mathrm{CH}_{3} \mathrm{COOH}$ ) are investigated in the presence of $0.5 \mathrm{~mL}$ of $(100 \mathrm{ppm})$ benzidine, $0.5 \mathrm{~mL}$ of $(1 \%) \quad \mathrm{NaNO}_{2}, \quad 0.5 \mathrm{~mL}$ of $(0.1 \%)$ sulphamic acid, $1 \mathrm{~mL}$ of carbofuran and $0.5 \mathrm{~mL}$ of $(1 \mathrm{M}) \mathrm{Na}_{2} \mathrm{CO}_{3}$ 
Table (1): Effect of Different Acids on Diazotization of Carbofuran

\begin{tabular}{|c|c|c|c|c|}
\hline \multirow{2}{*}{$\begin{array}{c}\text { Type of } \\
\text { acid }\end{array}$} & \multicolumn{3}{|c|}{ Absorbance } & $\begin{array}{c}\text { Mean } \\
\text { Absorbance }\end{array}$ \\
\cline { 2 - 4 } & $\mathrm{A}_{1}$ & $\mathrm{~A}_{2}$ & $\mathrm{~A}_{3}$ & 0.573 \\
\hline $\mathrm{HCl}$ & 0.553 & 0.568 & 0.600 & 0.082 \\
\hline $\mathrm{HNO}_{3}$ & 0.072 & 0.093 & 0.082 & 0.542 \\
\hline $\mathrm{CH}_{3} \mathrm{COOH}$ & 0.566 & 0.545 & 0.515 & 0.217 \\
\hline $\mathrm{H}_{2} \mathrm{SO}_{4}$ & 0.220 & 0.230 & 0.202 & 0.328 \\
\hline $\mathrm{H}_{3} \mathrm{PO}_{4}$ & 0.314 & 0.330 & 0.340 & 0.328 \\
\hline
\end{tabular}

It is found that $1 \mathrm{~mL}$ of $1 \mathrm{M} \mathrm{HCl}$ acid give the maximum absorbance more than other acids Table (1) and is used in all subsequent experiments.

\section{Effect of Volume of Hydrochloric Acid}

The effect of different volumes of $1 \mathrm{M}$ $\mathrm{HCl}$ solution on the absorbance of the colored product was studied as shown in Table (2)

Table (2): Effect of Volume of Hydrochloric Acid and Time in Absorbances intensity of aAzo Dye

\begin{tabular}{|c|c|c|c|c|c|c|}
\hline $\begin{array}{c}\text { Volume add of } \\
\text { HCL }\end{array}$ & $\mathrm{A}_{1} \cdot 1 \mathrm{~min}$ & $\mathrm{~A}_{2} \cdot 2 \mathrm{~min}$ & $\mathrm{~A}_{3} .3 \mathrm{~min}$ & $\mathrm{~A}_{4} \cdot 4 \mathrm{~min}$ & $\mathrm{~A}_{5} .5 \mathrm{~min}$ & Mean Absorbance \\
\hline 0.1 & 0.527 & 0.522 & 0.520 & 0.519 & 0.517 & 0.521 \\
\hline 0.2 & 0.553 & 0.559 & 0.561 & 0.562 & 0.570 & 0.561 \\
\hline 0.3 & 0.670 & 0.669 & 0.655 & 0.645 & 0646 & 0.657 \\
\hline 0.4 & 0.689 & 0.699 & 0.704 & 0.714 & 0.719 & 0.705 \\
\hline 0.5 & 0.069 & 0.072 & 0.078 & 0.082 & 0.089 & 0.079 \\
\hline 0.6 & 0.070 & 0.072 & 0.074 & 0.076 & 0.078 & 0.074 \\
\hline 0.7 & 0.067 & 0.064 & 0.060 & 0.058 & 0.055 & 0.061 \\
\hline 0.8 & 0.050 & 0.046 & 0.040 & 0.034 & 0.030 & 0.040 \\
\hline 0.9 & 0.022 & 0.029 & 0.038 & 0.033 & 0.042 & 0.033 \\
\hline
\end{tabular}

It is found that $0.4 \mathrm{~mL}$ of $1 \mathrm{M} \mathrm{HCl}$ acid is adequate for completing diazotization, and it give a maximum absorbance at $5 \mathrm{~min}$. Increasing in the volume of $\mathrm{HCl}$ solution causes a decrease in the absorbance of the reaction product (Table 2)

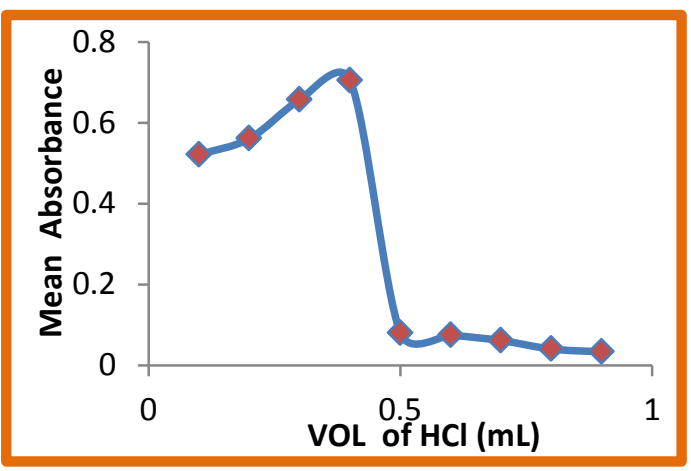

Fig. (3): The Effect of Hydrochloric Acid Volume The Absorbance of Carbofuran Which Demonstrates That The Best Volume of $\mathrm{HCl}$ is 0.4 mL. That Dependent for Further Optimization

Effect of the Type of the Alkaline Medium

Typically, coupling reaction of diazotized reagent with phenols is carried out in alkaline solution; therefore, the yellow colored product which is formed between carbofuran and benzidine has developed only in alkaline medium. The effect of different alkaline solutions (1M) such as potassium hydroxide, sodium carbonate, ammonium hydroxide, potassium carbonate and sodium hydroxide is studied.

Table (3):The Effect of the Type of Alkaline Medium on Diazotization of Carbofuran

\begin{tabular}{|c|c|c|c|c|}
\hline $\begin{array}{c}\text { Type of } \\
\text { base }\end{array}$ & $\mathrm{A}_{1}$ & $\mathrm{~A}_{2}$ & $\mathrm{~A}_{3}$ & $\begin{array}{c}\text { Mean } \\
\text { Absorbance }\end{array}$ \\
\hline $\mathrm{KOH}$ & 0.011 & 0.012 & 0.015 & 0.012 \\
\hline $\mathrm{NaOH}$ & 0.017 & 0.02 & 0.019 & 0.018 \\
\hline $\mathrm{Na}_{2} \mathrm{CO}_{3}$ & 0.301 & 0.310 & 0.307 & 0.306 \\
\hline $\mathrm{K}_{2} \mathrm{CO}_{3}$ & 0.150 & 0.154 & 0.159 & 0.154 \\
\hline $\mathrm{NH}_{4} \mathrm{OH}$ & 0.005 & 0.009 & 0.01 & 0.008 \\
\hline
\end{tabular}

The maximum sensitivity and stability are obtained, when the reaction is carried out in the presence of $1 \mathrm{~mL}$ of $1 \mathrm{M}$ sodium carbonate solution as shown in (Table3). 
Effect of Volume of Sodium Carbonate

The effect of different volumes of ( $1 \mathrm{M}$ )

$\mathrm{Na}_{2} \mathrm{CO}_{3}$ solution on the absorbance of the colored product is studied keeping other conditions constant.

Table (4) : Effect of volume of sodium carbonate and Time in absorbance intensity of dye

\begin{tabular}{|c|c|c|c|c|c|c|}
\hline $\begin{array}{c}\text { Volume add of } \\
\mathrm{Na}_{2} \mathrm{CO}_{3}\end{array}$ & $\mathrm{~A}_{1} \cdot 1 \mathrm{~min}$ & $\mathrm{~A}_{2} \cdot 2 \mathrm{~min}$ & $\mathrm{~A}_{3} .3 \mathrm{~min}$ & $\mathrm{~A}_{4} .4 \mathrm{~min}$ & $\mathrm{~A}_{5} .5 \mathrm{~min}$ & Mean Absorbance \\
\hline 0.1 & 0.511 & 0.500 & 0.535 & 0.555 & 0.534 & 0.527 \\
\hline 0.2 & 0.546 & 0.579 & 0.578 & 0.580 & 0.578 & 0.572 \\
\hline 0.3 & 0.612 & 0.622 & 0.620 & 0.665 & 0.678 & 0.639 \\
\hline 0.4 & 0.650 & 0.659 & 0.686 & 0.681 & 0.667 & 0.668 \\
\hline 0.5 & 0.665 & 0.679 & 0.848 & 0.655 & 0.680 & 0.705 \\
\hline 0.6 & 0.803 & 0.709 & 0.611 & 0.665 & 0.622 & 0.682 \\
\hline 0.7 & 0.501 & 0.406 & 0.444 & 0.512 & 0.522 & 0.477 \\
\hline 0.8 & 0.470 & 0.468 & 0.436 & 0.435 & 0.400 & 0.441 \\
\hline 0.9 & 0.411 & 0.309 & 0.415 & 0.337 & 0.356 & \\
\hline
\end{tabular}

It was found that a maximum absorbance and stable color is established with $0.5 \mathrm{~mL}$ of sodium carbonate (Table 4). Thus $0.5 \mathrm{~mL}$ of $1 \mathrm{M}$ $\mathrm{Na}_{2} \mathrm{CO}_{3}$ is chosen in all subsequent experiments as shown in Figure (4).

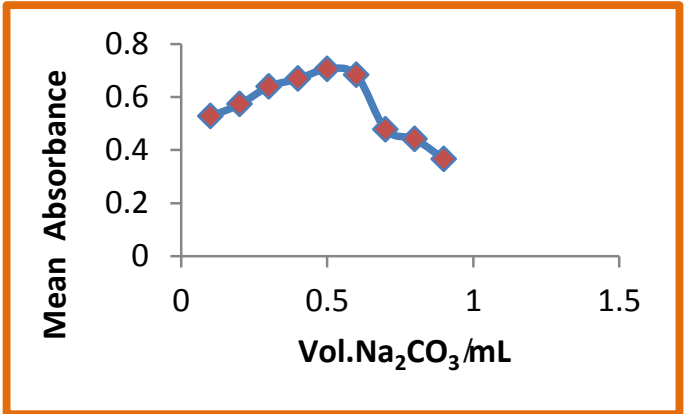

Fig. (4): The Effect of Alkaline Volume on Absorbance of Complex of Carbofuran with Benzidine

Effect of Nitrite Time and Amount on Absorbance of Azo Dye

The effect of different amounts 0.1- 0.9 $\mathrm{mL}$ of $1 \%$ sodium nitrite with time on the absorbance of the consequential azo dye has undergone a careful study.

Table (5): Effect of Sodium Nitrite Time and Amount on Absorbance

\begin{tabular}{|c|c|c|c|c|c|c|}
\hline $\begin{array}{c}\text { volume add of } \\
\mathbf{N a N O}_{2}\end{array}$ & $\mathrm{~A}_{1} \cdot 1 \mathrm{~min}$ & $\mathrm{~A}_{2} .2 \mathrm{~min}$ & $\mathrm{~A}_{3} .3 \mathrm{~min}$ & $\mathrm{~A}_{4} .4 \mathrm{~min}$ & $\mathrm{~A}_{5} .5 \mathrm{~min}$ & Mean Absorbance \\
\hline 0.1 & 0.413 & 0.411 & 0.415 & 0.420 & 0.422 & 0.416 \\
\hline 0.2 & 0.450 & 0.451 & 0.465 & 0.453 & 0.460 & 0.455 \\
\hline 0.3 & 0.512 & 0.490 & 0.499 & 0.560 & 0.597 & 0.531 \\
\hline 0.4 & 0.618 & 0.630 & 0.670 & 0.673 & 0.875 & 0.693 \\
\hline 0.5 & 0.709 & 0.715 & 0.630 & 0.675 & 0.612 & 0.668 \\
\hline 0.6 & 0.560 & 0.573 & 0.570 & 0.523 & 0.524 & 0.550 \\
\hline 0.7 & 0.525 & 0.468 & 0.489 & 0.478 & 0.412 & 0.474 \\
\hline 0.8 & 0.434 & 0.456 & 0.472 & 0.424 & 0.406 & 0.438 \\
\hline 0.9 & 0.422 & 0.426 & 0.413 & 0.420 & 0.337 & 0.403 \\
\hline
\end{tabular}

The results in (Table 5) show that 0.4 $\mathrm{mL}$ of $1 \%$ sodium nitrite solution at 5 min as a reaction time is optimal and it is recommended for the subsequent experiments shown in Figure (5). 


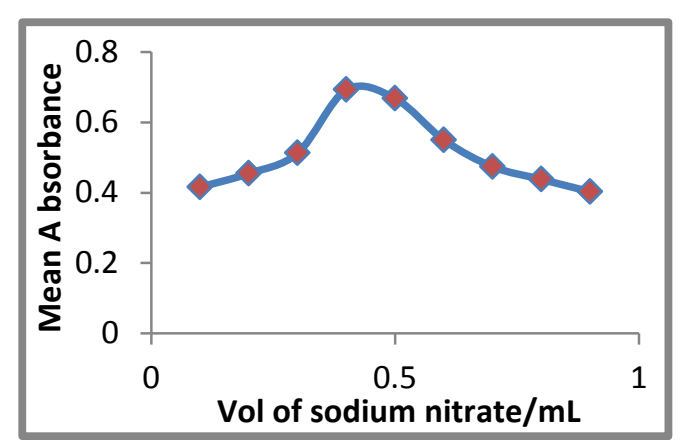

Fig. (5): Effect of Sodium Nitrite Amount and Time on Absorbance
Effect of Sulphamic Acid Amount and Time

The effect of different amounts 0.1- 0.9 $\mathrm{mL}$ of $0.1 \%$ sulphamic acid with time on the absorbance of the resulting azo dye is studied The excess of nitrite must be removed by adding sulphamic solution due to high blank values.

Table (6): Effect of Sulphamic Acid Amount and Time on Absorbance

\begin{tabular}{|c|c|c|c|c|c|c|}
\hline $\begin{array}{c}\text { Volume . add of } \\
\text { sulphamic acid }\end{array}$ & $\mathrm{A}_{1} .1 \mathrm{~min}$ & $\mathrm{~A}_{2} .2 \mathrm{~min}$ & $\mathrm{~A}_{3} .3 \mathrm{~min}$ & $\mathrm{~A}_{4} .4 \mathrm{~min}$ & $\mathrm{~A}_{5} .5 \mathrm{~min}$ & Mean Absorbance \\
\hline 0.1 & 0.533 & 0.539 & 0.537 & 0.540 & 0.542 & 0.538 \\
\hline 0.2 & 0.568 & 0.566 & 0.571 & 0.574 & 0.576 & 0.571 \\
\hline 0.3 & 0.657 & 0.660 & 0.662 & 0.664 & 0.665 & 0.661 \\
\hline 0.4 & 0.614 & 0.618 & 0.619 & 0.622 & 0.623 & 0.619 \\
\hline 0.5 & 0.582 & 0.583 & 0.585 & 0.587 & 0.589 & 0.585 \\
\hline 0.6 & 0.515 & 0.517 & 0.519 & 0.525 & 0.523 & 0.519 \\
\hline 0.7 & 0.480 & 0.483 & 0.485 & 0.486 & 0.487 & 0.484 \\
\hline 0.8 & 0.420 & 0.421 & 0.424 & 0.427 & 0.430 & 0.424 \\
\hline 0.9 & 0.358 & 0.360 & 0.362 & 0.365 & 0.361 & 0.361 \\
\hline
\end{tabular}

The experimental results reveal that 0.3 $\mathrm{mL}$ of $0.1 \%$ sulphamic acid with $5 \mathrm{~min}$ as time can be incorporated for the development of the formed colored azo dye as shown in Table and Figure (6)

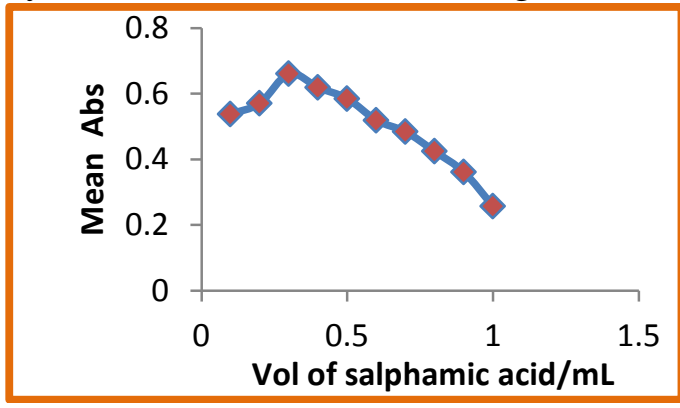

Fig. (6):The Effect of Salphamic Acid Volume on Absorbance of Complex of Carbofuran with Benzidine

\section{Effect of coupling reagent}

The effect of varying concentration of coupling reagent is studied using the proposed procedure and adding 0.1-0.9 $\mathrm{mL}$ of $100 \mathrm{ppm}$ of benzidine to a series solution.
Table (7): Effect of Benzidine Amount and Time on Absorbance

\begin{tabular}{|c|c|c|c|c|c|c|}
\hline $\begin{array}{c}\text { volum } \\
\text { e add } \\
\text { of } \\
\begin{array}{c}\text { Benzid } \\
\text { ine }\end{array}\end{array}$ & $\begin{array}{c}\mathrm{A}_{1} .1 \\
\mathrm{~min}\end{array}$ & $\begin{array}{c}\mathrm{A}_{2} .2 \\
\mathrm{~min}\end{array}$ & $\begin{array}{c}\mathrm{A}_{3} .3 \\
\mathrm{~min}\end{array}$ & $\begin{array}{c}\mathrm{A}_{4} .4 \\
\mathrm{~min}\end{array}$ & $\begin{array}{c}\mathrm{A}_{5} .5 \\
\mathrm{~min}\end{array}$ & $\begin{array}{c}\text { Mean } \\
\text { Absorba } \\
\text { nce }\end{array}$ \\
\hline 0.1 & 0.743 & 0.744 & 0.745 & 0.747 & 0.750 & 0.745 \\
\hline 0.2 & 0.768 & 0.771 & 0.772 & 0.774 & 0.776 & 0.772 \\
\hline 0.3 & 0.767 & 0.777 & 0.775 & 0.776 & 0.780 & 0.774 \\
\hline 0.4 & 0.752 & 0.755 & 0.758 & 0.760 & 0.763 & 0.757 \\
\hline 0.5 & 0.726 & 0.730 & 0.732 & 0.738 & 0.739 & 0.733 \\
\hline 0.6 & 0.721 & 0.724 & 0.725 & 0.729 & 0.735 & 0.726 \\
\hline 0.7 & 0.719 & 0.717 & 0.715 & 0.722 & 0.725 & 0.719 \\
\hline 0.8 & 0.706 & 0.709 & 0.713 & 0.718 & 0.714 & 0.712 \\
\hline 0.9 & 0.691 & 0.693 & 0.695 & 0.698 & 0.601 & 0.675 \\
\hline
\end{tabular}

It is found that maximum absorbance and stable color is formed with $0.3 \mathrm{ml}$ at $5 \mathrm{~min}$ of benzidine in final volume of $10 \mathrm{~mL}$.

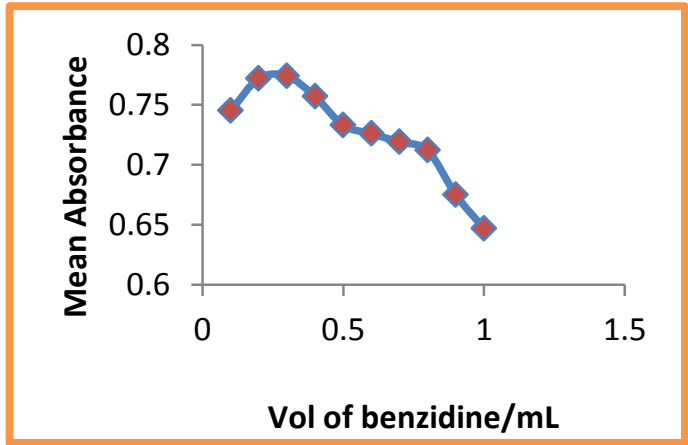

Fig. (7): The Effect of Benzidine Volume on Absorbance of Carbofuran 


\section{Effect of Surfactant Type}

The experiments are conducted at optimum established conditions according to the general procedure by using various type of surfactants such as, Tween20, SDS. CTAP and Triton
$\mathrm{X}-100$ at optimum concentration of $0.1 \%$ for each species. In each case, the respective $\lambda$ max for each surfactant used and absorbance are calculated to choose the best one.

Table . (8) Effect of Surfactant Type on Absorbance

\begin{tabular}{|c|c|c|c|c|c|}
\hline Surfactant & CTAB & SDS & Triton $\times-80$ & Tween 20 & Before addition \\
\hline Absorbance & 0.706 & 0.478 & 0.556 & 0.775 & 0.454 \\
\hline
\end{tabular}

It is observed that Tween 20 which has maximum absorbance at $429 \mathrm{~nm}$ is the best one for further study as shown in (Table 8)

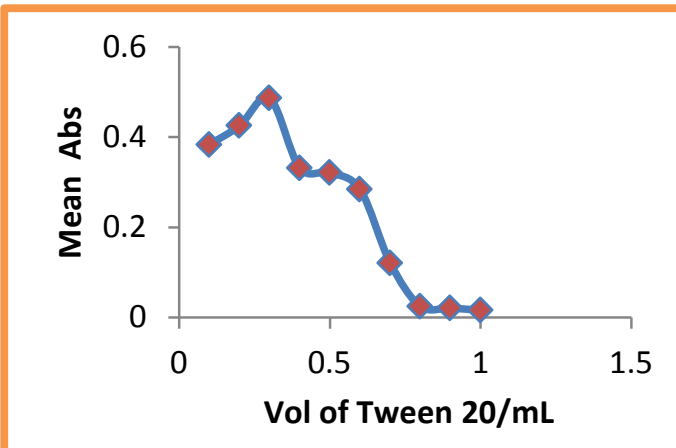

Fig. (8).The Effect of Tween 20 Volume on Absorbance of the Complex of Carbofuran Formed with Benzidine.

The data above of Table and Figure (8) demonstrate that $0.3 \mathrm{ml}$ the best volume of Tween 20 that is dependent on further Study

\section{Effect of Organic Solvents}

Different organic solvents are examined to evaluate their effects on the intensity of the azo dye which form the data as shown in ( Table 9).
Table (9): Effect of Water and Organic Solvents on the Optical Properties of the Azo Dye

\begin{tabular}{|c|c|c|c|c|}
\hline \multirow{2}{*}{ Type of solvent } & \multicolumn{3}{|c|}{ Absorbance } & \multirow{2}{*}{ Average } \\
\cline { 2 - 4 } & $\mathrm{A}_{1}$ & $\mathrm{~A}_{2}$ & $\mathrm{~A}_{3}$ & \\
\hline Water & 0.501 & 0.503 & 0.502 & 0.502 \\
\hline Chloroform & 0.259 & 0.262 & 0.260 & 0.260 \\
\hline Ethanol & 0.483 & 0.485 & 0.487 & 0.485 \\
\hline Methanol & 0.504 & 0.508 & 0.515 & 0.509 \\
\hline Hexane & 0.100 & 0.101 & 0.103 & 0.101 \\
\hline Dichloromethan & 0.189 & 0.190 & 0.194 & 0.191 \\
\hline $\begin{array}{c}\text { Methyl ethyl } \\
\text { ether }\end{array}$ & 0.157 & 0.161 & 0.162 & 0.160 \\
\hline Benzen & 0.366 & 0.365 & 0.367 & 0.366 \\
\hline $\begin{array}{c}\text { Hydrogen } \\
\text { peroxide }\end{array}$ & 0.370 & 0.369 & 0.371 & 0.370 \\
\hline
\end{tabular}

\section{Effect of Interference}

The effect of some foreign organic compounds and Inorganic compounds, often found in environmental, are studied by adding equal amount of $1 \mathrm{~mL}$ of (10ppm) of organic compounds, Inorganic compounds and phenols to $1 \mathrm{~mL}$ of $(10 \mathrm{ppm})$ of carbofuran. The color is developed by following the recommended procedure described earlier.

Table (10) Effect of Interference

\begin{tabular}{|c|c|c|}
\hline $\begin{array}{c}\text { Type of interference } \\
(\mathbf{1} \mathbf{m L})\end{array}$ & $\begin{array}{c}\text { Mean } \\
\text { Absorbance }\end{array}$ & RSD\% \\
\hline Non addition & 0.572 & 0.524 \\
\hline Lactose & 0.069 & 1.449 \\
\hline Succrouse & 0.083 & 1.204 \\
\hline Potassium nitrate & 0.050 & 2.0 \\
\hline Potassium chloride & 0.041 & 1.396 \\
\hline Urea & 0.092 & 1.086 \\
\hline Benzoic acid & 0.088 & 2.838 \\
\hline Benzoyl peroxide & 0.095 & 2.785 \\
\hline bendiocarb & 0.078 & 2.657 \\
\hline Magnesium nitrate & 0.036 & 2.777 \\
\hline
\end{tabular}


It is observed the Table (10) above, the foreign organic compounds and inorganic compounds do not interfering with the determination carbofuran

\section{Effect of Additing Order}

Different orders of addition are examined, as Shown in (Table11)

Table (11): Effect of Additing Order

\begin{tabular}{|c|c|c|}
\hline number & Addition order & Absorbance \\
\hline I & $\mathrm{R}+\mathrm{H}+\mathrm{N}+\mathrm{F}+\mathrm{C}+\mathrm{B}+\mathrm{T}$ & 0.418 \\
\hline II & $\mathrm{R}+\mathrm{H}+\mathrm{N}+\mathrm{F}+\mathrm{T}+\mathrm{C}+\mathrm{B}$ & 0.468 \\
\hline III & $\mathrm{R}+\mathrm{H}+\mathrm{T}+\mathrm{N}+\mathrm{F}+\mathrm{R}+\mathrm{C}$ & 0.530 \\
\hline IV & $\mathrm{C}+\mathrm{R}+\mathrm{N}+\mathrm{H}+\mathrm{F}+\mathrm{T}+\mathrm{B}$ & 0.562 \\
\hline V & $\mathrm{C}+\mathrm{H}+\mathrm{N}+\mathrm{T}+\mathrm{F}+\mathrm{R}+\mathrm{B}$ & 0.490 \\
\hline VI & $\mathrm{R}+\mathrm{N}+\mathrm{H}+\mathrm{F}+\mathrm{C}+\mathrm{B}+\mathrm{T}$ & 0.463 \\
\hline VII & $\mathrm{C}+\mathrm{N}+\mathrm{H}+\mathrm{F}+\mathrm{R}+\mathrm{T}+\mathrm{B}$ & 0.429 \\
\hline VIII & $\mathrm{C}+\mathrm{H}+\mathrm{N}+\mathrm{F}+\mathrm{R}+\mathrm{B}+\mathrm{T}$ & 0.450 \\
\hline IX & $\mathrm{C}+\mathrm{H}+\mathrm{N}+\mathrm{F}+\mathrm{T}+\mathrm{R}+\mathrm{B}$ & 0.502 \\
\hline
\end{tabular}

$\mathrm{C}$ :(carbofuran), $\mathrm{R}:($ benzindine), $\mathrm{H}:(\mathrm{HCl}), \quad \mathrm{N}:\left(\mathrm{NaNO}_{2}\right), \quad \mathrm{B}:\left(\mathrm{Na}_{2} \mathrm{CO}_{3}\right)$, $\mathrm{F}$ :(Sulphamic acid) T:(Tween 20)It is found from the data in Table (11) that the order $(\mathrm{C}+\mathrm{R}+\mathrm{N}+\mathrm{H}+\mathrm{F}+\mathrm{T}+\mathrm{B})$ gives maximum color intensity and was used in all subsequent experiments

\section{Effect of Temperature}

The effect of temperature on the color intensity of the product is studied (Table 12). Maximum absorbance is obtained when the color is developed at room temperature
Table (12): Effect of Temperature on the Color Intensity of the Product Was Studied .

\begin{tabular}{|c|c|c|c|c|}
\hline $\begin{array}{c}\text { Time. } \\
(\mathbf{m i n})\end{array}$ & $\mathbf{0 . 0}$ & $\begin{array}{c}\text { Room.T } \\
\mathbf{2 5} \mathbf{C}\end{array}$ & $\mathbf{4 0}^{\circ} \mathbf{C}$ & $\mathbf{5 0}^{\circ} \mathbf{C}$ \\
\hline 5 & 0.679 & 0.607 & 0.660 & 0.698 \\
\hline 10 & 0.618 & 0.627 & 0.651 & 0.629 \\
\hline 15 & 0.633 & 0.630 & 0.635 & 0.646 \\
\hline 20 & 0.640 & 0.634 & 0.628 & 0.606 \\
\hline 25 & 0.648 & 0.636 & 0.640 & 0.607 \\
\hline 30 & 0.656 & 0.657 & 0.663 & 0.681 \\
\hline 35 & 0.660 & 0.698 & 0.698 & 0.685 \\
\hline 40 & 0.665 & 0.700 & 0.718 & 0.695 \\
\hline 45 & 0.667 & 0.714 & 0.720 & 0.694 \\
\hline 50 & 0.666 & 0.720 & 0.690 & 0.720 \\
\hline 55 & 0.665 & 0.725 & 0.700 & 0.700 \\
\hline 60 & 0.670 & 0.726 & 0.710 & 0.714 \\
\hline
\end{tabular}

From the data in Table (12) it is recommended that the color reaction should be carried out at room temperature $\quad\left(25^{\circ} \mathrm{C}\right) . \quad$ Maximum absorbance is obtained when the color is developed at room temperature $\left(25^{\circ} \mathrm{C}\right)$ more than when the color is developed in an ice-bath $\left(0^{\circ} \mathrm{C}\right)$ or in a water-bath $\left(40{ }^{\circ} \mathrm{C}\right)$. and in a water-bath $\left(50{ }^{\circ} \mathrm{C}\right)$.In addition a loss in color intensity and stability is observed with increasing the temperature .

\section{Selected Optimum Conditions}

After studying the effect of different parameters that have impact on the absorbance intensity of the colored product, the optimum conditions for the proposed procedure are summarized in (Table 13) and are used in all subsequent experiments.

Table (13): The Optimum Conditions for the Determination of Carbofuran

\begin{tabular}{|c|c|c|c|}
\hline Optimum & Concentrations & Optimum quantities of solutions used & Observations \\
\hline $\mathrm{HCL}$ & $1 \mathrm{M}$ & $0.4 \mathrm{~mL}$ & Standing 5 minute time \\
\hline $\mathrm{NaNO}_{2}$ & $1 \%$ & $0.4 \mathrm{~mL}$ & Standing 5 minute time \\
\hline Sulphamic acid & $0.1 \%$ & $0.3 \mathrm{~mL}$ & Standing 5 minute time \\
\hline Carbofuran & $100 \mathrm{ppm}$ & $1 \mathrm{~mL}$ & \\
\hline Benzidine & $100 \mathrm{ppm}$ & $0.3 \mathrm{~mL}$ & Standing 5 minute time \\
\hline $\mathrm{Na}_{2} \mathrm{CO}_{3}$ & $1 \mathrm{M}$ & $0.5 \mathrm{~mL}$ & Standing 3minute time \\
\hline Tween 20 & $0.1 \%$ & $0.3 \mathrm{~mL}$ & Standing 3 minute time \\
\hline Total volume of solution & $\ldots \ldots$ & $\ldots \ldots$ & $3.2 \mathrm{~mL}$ in volumetric flask $(10 \mathrm{~mL})$ \\
\hline Temperature & $\ldots \ldots$ & $\ldots \ldots$ & Room.T \\
\hline Order of addition & $\ldots \ldots$ & $\ldots$ & IV \\
\hline$\lambda \max$ & $\ldots$ & $\ldots .$. & $429 \mathrm{~nm}$ \\
\hline \multicolumn{3}{|c|}{$\begin{array}{l}\text { Structure of the Dye } \\
\text { The stoicheiometry of the complex } \\
\text { formed between carbofuran and } \\
\text { benzidine is studied, it is observed that } \\
\text { benzidine reacts with increasing amount } \\
\text { of nitrite ion in the acidic medium to } \\
\text { from Diazonium ion }\end{array}$} & $2 \mathrm{H}^{+}+\mathrm{NO}_{2}^{-}$ \\
\hline
\end{tabular}


Adding sulphamic acid to prevent the side reactions with the dye formed which may be caused by the increase of sodium nitrite, which reacts with the increase of nitrite and produce free nitrogen gas

$\mathrm{NHO}_{2}+\mathrm{NH}_{2} \mathrm{SO}_{3} \mathrm{H} \longrightarrow \mathrm{N}_{2}+\mathrm{H}_{2} \mathrm{O}+\mathrm{H}_{2} \mathrm{SO}_{4}$

Nitrose acid Sulphamic acid

Then coupling Diazonium salt with carbofuran in the alkaline medium to get the yellow Azo Dye

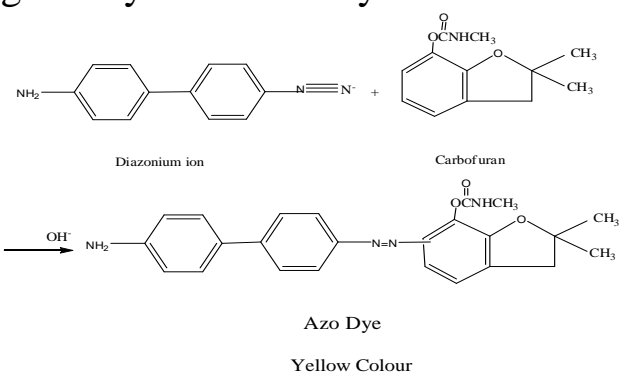

Fig.(9) Carbofuran Coupling with of Reagent

The reaction shows an absorption maxima at $429 \mathrm{~nm}$ named the molar absorpitivity of $10 \mathrm{ppm}$ is $\left(1 \times 10^{4} \mathrm{Lmol}^{-}\right.$ ${ }^{1} \mathrm{~cm}^{-1}$ )which means that the method can be used for direct determination of carbofuran depending on the absorption measurements of thecoupling product of carbofuran,

Calibration Curve A series of solution is prepared with deionized water at a known concentration of carbofuran $(0,2,4,6,8,10,12,14 \mathrm{ppm})$ in to $10 \mathrm{~mL}$ volumetric flasks and added $0.3 \mathrm{~mL}$ of benzidine, $0.4 \mathrm{~mL}$ of $1 \%$ of $\mathrm{NaNO}_{2}, 0.4 \mathrm{~mL}$ of $1 \mathrm{M}$ of $\mathrm{HCl}, 0.3 \mathrm{~mL}$ of $0.1 \%$ sulphamic acid and then added $0.3 \mathrm{~mL}$ of $0.1 \%$ Tween and then added $0.5 \mathrm{~mL}$ of $1 \mathrm{M} \mathrm{Na} \mathrm{NO}_{3}$ and filled to mark with distilled water to form a spiked samples. The absorbance measurements are carried out at a wavelength at $429 \mathrm{~nm}$. The concentrations are obtained from the calibration curve for the spiked solutions are shown in the (Table 14)
Table (14) The Absorbance Measurements of Standard Solution of Carbofuran in Alkaline Medium by using Distilled Water Samples.

\begin{tabular}{|c|c|c|c|c|}
\hline $\begin{array}{c}\text { Conc .ppm } \\
\text { of } \\
\text { carbofuran }\end{array}$ & $\begin{array}{c}\text { Avarage } \\
\text { absorbance }\end{array}$ & RSD\% & found & Recovery\% \\
\hline 2 & 0.121 & 1.65289 & 1.9907 & 99 \\
\hline 4 & 0.239 & 0.63735 & 4.1639 & 104 \\
\hline 6 & 0.351 & 0.4356 & 6.2265 & 103 \\
\hline 8 & 0.443 & 0.46954 & 7.9208 & 99 \\
\hline 10 & 0.562 & 0.27196 & 10.1123 & 101 \\
\hline 12 & 0.661 & 0.30257 & 11.9355 & 99 \\
\hline 14 & 0.765 & 0.27223 & 13.8508 & 98 \\
\hline
\end{tabular}

The calibration curve is drawn by using the mean absorbance as a function of concentration (ppm) as shown in Figure (10).

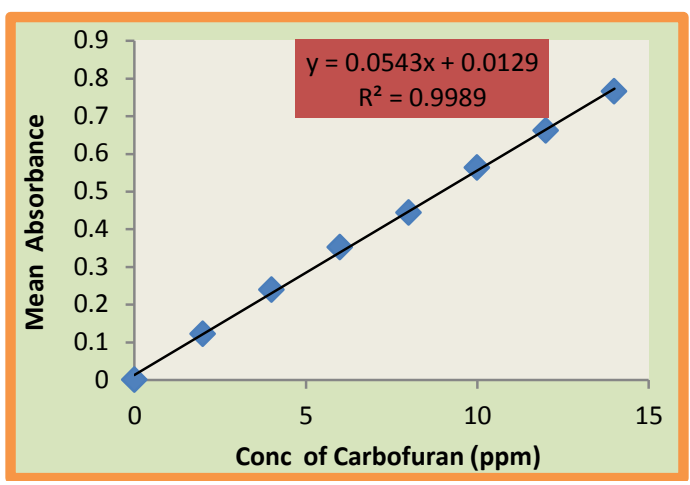

Fig. (10). Calibration curve of carbofuranin deionized water coupling with benzidine

Optical Characteristic Features of the Calibration Curve.

Table(15) shows the main features of the calibration curve and measuring the absorbance at $429 \mathrm{~nm}$

Table (15): Optical Characteristic Features of Calibration Curve

\begin{tabular}{|c|c|}
\hline Parameter & Values \\
\hline Color & yellow \\
\hline Wave length $\lambda_{\max }(\mathrm{nm})$ & 429 \\
\hline Beer's Law limit a $\left(\mu \mathrm{g} \mathrm{mL}^{-1}\right)$ & $0-14$ \\
\hline Molar absorpitivity $\left(\mathrm{mol}^{-1} \mathrm{~cm}^{-1} \mathrm{~L}\right)$ & $1 \times 10^{4}$ \\
\hline regression coefficient(r) & 0.9994 \\
\hline Correlation coefficient $\left(\mathrm{r}^{2}\right)$ & 0.9989 \\
\hline Sand ell's sensitivity $\left(\mu \mathrm{gcm}^{-2}\right)$ & 0.017783 \\
\hline Slope $(\mathrm{m})$ & 0.0543 \\
\hline Intercept (C) & 0.0129 \\
\hline Regression equation $(\mathrm{Y}=\mathrm{mX}+\mathrm{C})$ & $\begin{array}{c}\mathrm{y}=0.0543 \mathrm{x}+ \\
0.0129\end{array}$ \\
\hline Variation coefficient $(\%)$ & 99.89 \\
\hline Limit of detection $\left(\mu \mathrm{g} \mathrm{mL}^{-1}\right)$ & 0.314475 \\
\hline
\end{tabular}




\begin{tabular}{|c|c|}
\hline Limit of quantization $\left(\mu \mathrm{g} \mathrm{mL}^{-1}\right)$ & 1.048250 \\
\hline Average recovery $(\%)$ & 100.4 \\
\hline
\end{tabular}

From the data above in Table (15) we can see that the method in suitable for the direct determination of carbofuran in environmental water samples.

Direct Determination of Carbofuran in Spiked Neutral Water Samples .A series of solutions is prepared by spiking different environmental water samples with a known concentration of carbofuran $(0,2,4,6,8 \mathrm{ppm})$ into $25 \mathrm{~mL}$ volumetric flasks and filled to the mark with tap underground, river and rain waters to form spiked samples. The absorbance measurements are carried out at a wavelength at $429 \mathrm{~nm}$. The absorbance measurements and recovery percentages of carbofuran shown in the Table(16)

Table (16) Recovery of Carbofuran in the Spiked Water Sample Solutions.

\begin{tabular}{|c|c|c|c|c|c|}
\hline Type water & $\begin{array}{c}\text { present. } \\
\text { ppm }\end{array}$ & $\begin{array}{c}\text { Mean } \\
\text { Absorbance }\end{array}$ & RSD\% & $\begin{array}{l}\text { Found } \\
\text { (ppm) }\end{array}$ & Recovery\% \\
\hline \multirow{4}{*}{ Tap water } & 2 & 0.119 & 1.6806 & 1.9539 & 97 \\
\hline & 4 & 0.221 & 0.4524 & 3.8324 & 95 \\
\hline & 6 & 0.334 & 0.7921 & 5.9134 & 98 \\
\hline & 8 & 0.427 & 0.4871 & 7.6261 & 95 \\
\hline \multirow{4}{*}{$\begin{array}{l}\text { Underground } \\
\text { water }\end{array}$} & 2 & 0.122 & 2.1686 & 2.0092 & 100 \\
\hline & 4 & 0.218 & 0.9534 & 3.7771 & 94 \\
\hline & 6 & 0.326 & 0.6378 & 5.7661 & 96 \\
\hline & 8 & 0.446 & 0.2242 & 7.9760 & 99 \\
\hline \multirow{4}{*}{ River water } & 2 & 0.115 & 0.8695 & 1.8802 & 94 \\
\hline & 4 & 0.240 & 0.8685 & 4.1823 & 104 \\
\hline & 6 & 0.347 & 0.5993 & 6.1528 & 102 \\
\hline & 8 & 0.455 & 0.2197 & 8.1418 & 101 \\
\hline \multirow{4}{*}{ Rain water } & 2 & 0.127 & 1.6348 & 2.1012 & 105 \\
\hline & 4 & 0.229 & 0.9077 & 3.9797 & 99 \\
\hline & 6 & 0.342 & 0.7736 & 6.0607 & 101 \\
\hline & 8 & 0.431 & 0.2320 & 7.6998 & 96 \\
\hline
\end{tabular}

The results in Table (16) reveral that the percent recovery is from 95 to $98 \%$ for tap water, 94 to $100 \%$ for underground water,94 to $104 \%$ for River water and96 to $105 \%$ for Rain water indicating that the method is suitable for direct determination of carbofuran in environmental water samples and with the interference of very low .

\section{Continuous Variation Method(Job`s method) [13]}

A series of $(1,2,3,4,5,6,7,8,9) \mathrm{mL}$ of $\left(5 \times 10^{-4}\right) \mathrm{mol} \mathrm{L}^{-1}$ of the solution that contain carbofuran is pipette into each of $(10 \mathrm{~mL})$ volumetric flask then( $9,8,7,6,5,4,3,2,1) \mathrm{mL}$ of $\left(5 \times 10^{-4}\right) \mathrm{mol}$ $\mathrm{L}^{-1}$ of reagent ,the absorbance of the solutions is measured at $\lambda_{\max } 429 \mathrm{~nm}$ the stoichiometric ratio between carbofuran and reagent $1: 1$ results are shown in the Plotting the value of absorbance versus the VC / VT is shown in Figure (11)
Table (17): The Continuous Variation Method of Carbofuran and Benzidine Complex.

\begin{tabular}{|c|c|c|c|}
\hline$V C \boldsymbol{m} l$ & $V R \boldsymbol{m} \boldsymbol{l}$ & $\boldsymbol{V} \boldsymbol{C} \boldsymbol{V T}$ & Absorbance at $\boldsymbol{\lambda}=\mathbf{4 2 9}$ forColor compound \\
\hline 1 & 9 & 0.1 & 0.11 \\
\hline 2 & 8 & 0.2 & 0.219 \\
\hline 3 & 7 & 0.3 & 0.349 \\
\hline 4 & 6 & 0.4 & 0.502 \\
\hline 5 & 5 & 0.5 & 0.565 \\
\hline 6 & 4 & 0.6 & 0.498 \\
\hline 7 & 3 & 0.7 & 0.351 \\
\hline 8 & 2 & 0.8 & 0.245 \\
\hline 9 & 1 & 0.9 & 0.128 \\
\hline
\end{tabular}

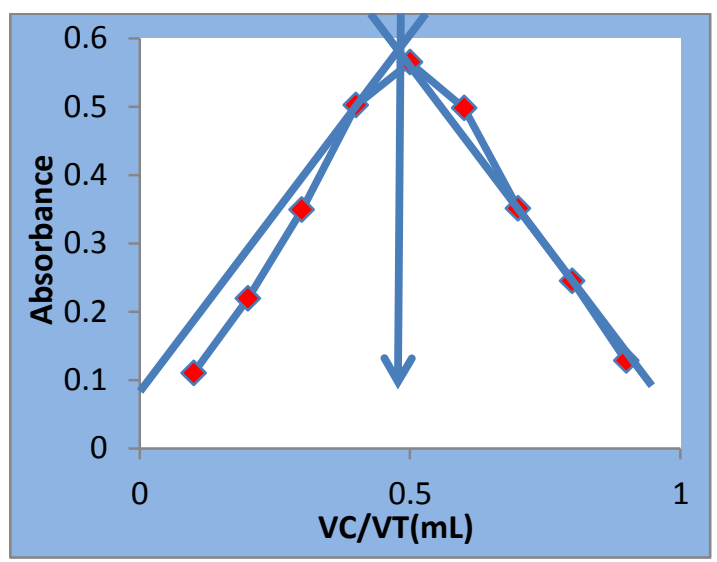

Fig. (11) Continuous Variation Plot. 
VC :The values of the compound ( carbofuran).

$\mathrm{VR}$ :The values of the reagent (benzidine).

VT: Total (VC+VR)

\section{Mole Ratio Method [13]}

Aliquots of $10 \mathrm{ml}$ solution containing $1 \mathrm{~mL}$ of $\left(5 \times 10^{-4}\right) \mathrm{mol} \mathrm{L}^{-1}$ of $(1 \mathrm{~mL})$ carbofuran and increasing concentrations $\left(5 \times 10^{-4}\right) \quad \mathrm{mol} \mathrm{L}^{-1}$ of $(0.1,0.2,0.4,0.6,0.8,1.0,1.2,1.4,1.6 \mathrm{~mL})$ of benzidine $\left(5 \times 10^{-6}--8 \times 10^{-6}\right) \mathrm{molL}^{-}$ ${ }^{1}$ reagent. The absorbance of the solutions is measured versus blank at $\lambda_{\max }=429 \mathrm{~nm}$ the stoichiometric ratio is of 1:1and results are shown in the Table (18)

Table(18) The Mole Ratio Method of The Carbofuran and Benzidine Complex.

\begin{tabular}{|c|c|c|}
\hline $\boldsymbol{C L}$ & $\boldsymbol{C L} / \boldsymbol{C M}$ & Absorbance at $\boldsymbol{\lambda}=\mathbf{4 2 9} \mathbf{n m}$ \\
\hline $5 \times 10^{-6}$ & 0.1 & 0.125 \\
\hline $1 \times 10^{-5}$ & 0.2 & 0.135 \\
\hline $2 \times 10^{-5}$ & 0.4 & 0.178 \\
\hline $3 \times 10^{-5}$ & 0.6 & 0.223 \\
\hline $4 \times 10^{-5}$ & 0.8 & 0.276 \\
\hline $5 \times 10^{-5}$ & 1.0 & 0.304 \\
\hline $6 \times 10^{-5}$ & 1.2 & 0.347 \\
\hline $7 \times 10^{-5}$ & 1.4 & 0.373 \\
\hline $8 \times 10^{-5}$ & 1.6 & 0.389 \\
\hline
\end{tabular}

Plotting the value of absorbance versus the $C L / C M$ is shown in Figure ( 12 )

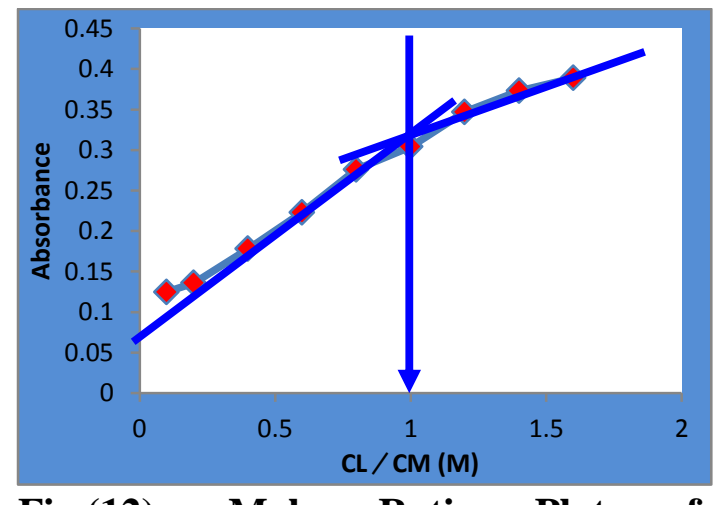

Fig.(12): Mole Ratio Plot of Carbofuran and Benzidine Complex.

CL: The concentration of the reagent(benzidine)

CM: The concentration of the compound (carbofuran)

Stability Constant of Reaction Product [13-14]

The conditional or apparent stability constant of the 1:1 (Reagent and carbofuran) product is evaluated as described
Complete founding the stability constant [K] of colored product Formed imputation of ( Regent :carbofuran) as follows :

A series of solution is prepared containing three different concentrations of reagent and carbofuran the concentration $\left(5 \times 10^{-4}\right) \mathrm{mol} \mathrm{L}^{-1}$ for Each reagent and carbofuran when Forming imputation under this condition easily to Hydrolysis and the Intensity absorption are very low.

Another series of solution is prepared containing three different concentration of reagent and carbofuran but with abundance of the reagent (the best concentration) The complex is prepared of the intensity absorption $A_{m}$ and application the relationship we can calculate the value degree of decomposition follows $(\alpha)$ :

$\alpha=\frac{A_{m}-A_{s}}{A_{m}}$

Stability constant $[\mathrm{K}]$ as follows ;

$S+R \rightarrow S R$

$$
\begin{aligned}
& \alpha c \quad(1-\alpha) c \\
& K=\frac{[S R]}{[S][R]} \\
& K=\frac{(1-\alpha) c}{(\alpha c)(\alpha c)}=\frac{1-\alpha}{\alpha^{2} c}
\end{aligned}
$$

Where: K; stability constant $\mathrm{C}$; the concentration of the product complex and it equivalence the concentration of carbofuran.are shown in the Table19

Table(19) Stability Constant of the Dye Formed

\begin{tabular}{|c|c|c|c|c|}
\hline \multirow{2}{*}{$\begin{array}{c}\text { Vol of } \\
\text { carbofuran }\end{array}$} & \multicolumn{4}{|c|}{ Absorbance at $\boldsymbol{\lambda}=\mathbf{4 2 9} \mathbf{n m}$} \\
\cline { 2 - 5 } & $\mathbf{A}_{\mathbf{s}}$ & $\mathbf{A}_{\mathbf{m}}$ & $\boldsymbol{\alpha}$ & $\mathbf{K}\left(\mathbf{l} . \mathbf{m o l}^{-2}\right)$ \\
\hline 0.5 & 0.220 & 0.225 & 0.0222 & $4.8 \times 10^{6}$ \\
\hline 0.7 & 0.224 & 0.336 & 0.3333 & $1.20 \times 10^{4}$ \\
\hline 0.9 & 0.335 & 0.450 & 0.2555 & $2.28 \times 10^{4}$ \\
\hline
\end{tabular}

\section{Conclusion:}

The proposed method is simple, sensitive and free from drastic experimental conditions such as heating. It is also accurate and precise enough to be successfully adopted as an alternative 
to the existing spectrophotometric method and evaluation of carbofuran in an electrophilic compound using Diazotization and in Environmental samples.

\section{References:}

[1]Manuel, A.; Garcia, R. L. C. M. J.; Rodriguez, D. P. and Slmanl, G. J. 2005. Influence of Micelles on the Basic Degradation of Carbofuran. J. Agric. Food Chem. 53: 7172-7178.

[2]Mohamed, S. J.; Moamed, A. F. and Ahamed, M. A. 2011. Adsorption of carbofuran insecticide from aqueous solution using commercial activated, Int. J. Chem. Sci. 9(2):557-564.

[3]AL-Rawi, S. M. Sh. 2011. Quantitative Analysis of some nsecticidos and their Mixture in Agricul by using uv-vis Spectrophotometer. Baghdad Sci. J. 8(2): 274-279.

[4]Al-Niaeem, Abd-Alsatar, M. Th. Mahmood, I. A. Adin, H. and Mohammed, A. 2014. Effect of the fungus Metarhizumanisopliae (Metchnikoff) Sorokin and actelic insecticide in the protection of bean seeds packaged in bag from infection by cowpea beetle. Baghdad Sci. J. 11(2): 908-912.

[5]Rama, B.; Swanandi, p.; Vidya, T. and Bipinraj, N. 2011. Developments in Analytical Methods for Detection of Pesticides in Environmental Samples. American J. Chem Analytical. 2:1-15

[6] Cook, R. F.; Stanovick, R. P. and Cassil, C. C. 1969. Chromatographic techniques in the analysis of organochlorine pesticide residues $\mathrm{J}$. Chromatography 754(22): 33-42.

[7]Ling, C. F.; Melian, G. P.; JimenezConde, F. and Revilla, E. 1990.
Comparative study of some columns for direct determination of carbofuran by gas-liquid chromatography with nitrogen-specific detection. J. Chromatography A 519(2):359-362.

[8]Agrawal, O. and Gupta, V. K. 1999. Sub-Parts-per-Million

Spectrophotometric Determination of Phenol and Related Pesticides Using Diazotized $p$-Amino-acetophenone. J. Microchemical: 62 (1):147-153

[9]Hirokawa, T.; Ohmori, A. and Kiso, Y. 1993. Analysis of a dilute sample by capillary zone electrophoresis with isotachophoretic preconcentration. Journal of Chromatography 634 (1):101-106

[10] McGarvey, B. D. 1993. Highperformance liquid chromatographic methods for the determination of $\mathrm{N}$ methylcarbamate pesticides in water. soil, plants and air J. Chromatography A . 642(1): 88-105.

[11] Nagaraja, P. and Bhaskara, B. L. 2006. Sensitive spectrophotometric assessment of carbofuran using dapsone as a new chromogenic reagent in formulations and environmental samples .31(4) 16784618

[12] Trotter, D.; Kent, R. and Wong, M. 1991. Aquatic Fate and Effect of Carbofuran. Crit Rev in Environ Cont 21(2): 137-176

[13] de-Levie, R. 1997. Principles of Quantitative Chemical Analysis J. Chromatography A 646 (2): 317329.

[14] Hadjiioannou , T. P .; Christian, G. D.; Koupparis, M. A. and Macheras, P. E.1993. Quantitative Calculations in Pharmaceutical Practice \& Research, VCH Publishers, Inc. USA. 


\section{التقدير الطيفي للكاربوفيوران با ستخدام ازوتة البنزيدين في نماذج المياة للبيئة شذى فاضل نارين

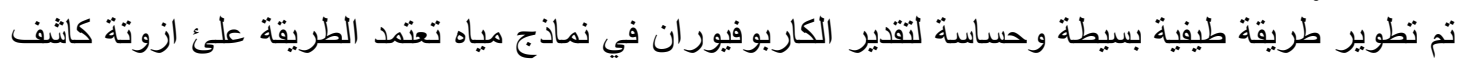

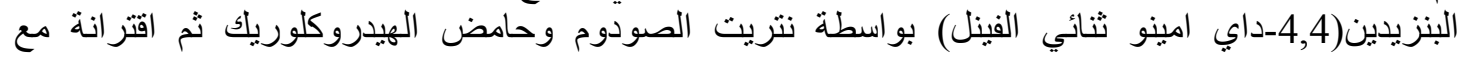

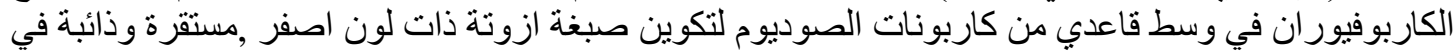

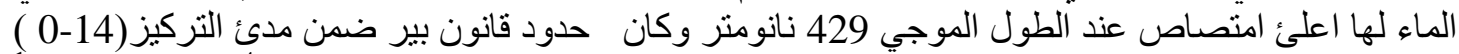

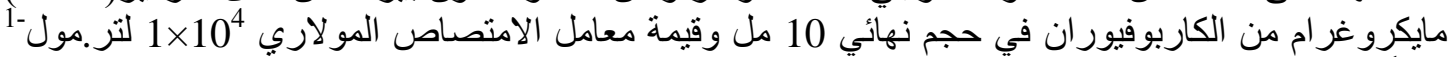

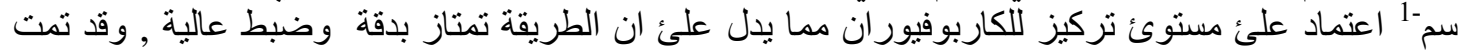

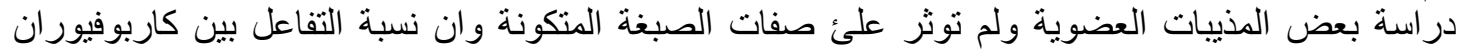
و البنزيدين هي 1:1 وقد طبقت الطريقة بنجاح لتقدير الكاربوفيور ان في نماذج المياة ( مياة الثرب، البئر ، النهر،

الكلمات المفتاحية: الكاربوفيوران، تقدير ، صبغة الازو، البنزيدين ، المطيافية 